\title{
Synthesis of 4A Zeolite and Characterization of Calcium- and Silver-Exchanged Forms
}

\author{
Saeed Golbad, Parisa Khoshnoud, Nidal Abu-Zahra* \\ Department of Materials Science and Engineering, University of Wisconsin-Milwaukee, Milwaukee, WI, USA \\ Email: *nidal@uwm.edu
}

How to cite this paper: Golbad, S., Khoshnoud, P. and Abu-Zahra, N. (2017) Synthesis of $4 \mathrm{~A}$ Zeolite and Characterization of Calcium- and Silver-Exchanged Forms. Journal of Minerals and Materials Characterization and Engineering, 5, 237-251.

https://doi.org/10.4236/jmmce.2017.55020

Received: July 5, 2017

Accepted: August 6, 2017

Published: August 9, 2017

Copyright $\odot 2017$ by authors and Scientific Research Publishing Inc. This work is licensed under the Creative Commons Attribution International License (CC BY 4.0).

http://creativecommons.org/licenses/by/4.0/

\begin{abstract}
Calcium exchanged A type zeolite is extensively used as an adsorbent in petroleum and gas purification application. The precursor of calcium and silver-exchanged zeolite was prepared in a hydrothermal process, followed by an exchange process. In this study, LTA zeolite was synthesized. Calcium-exchanged and silver-exchanged molecular sieves were prepared and characterized by a series of techniques, such as scanning electron microscopy, X-ray diffraction, X-ray photoelectron spectroscopy, etc. Physical properties of Caand Ag-exchanged zeolite A, such as surface structure, crystal structure, cation exchange capacity, and the ion-exchange properties were measured. Water adsorption studies using thermogravimetric method indicated that water molecules are more strongly bound in the Ca-A zeolite compared to Ag-A zeolite. XPS studies confirmed the presence of highly dispersed cationic silver species at exchange sites. The results of this study indicated that sodium was successfully exchanged with the calcium and silver in both Ca- and Ag-exchanged zeolite frameworks. High cation exchange capacity, tailored aperture size, high porosity and specific surface area, as well as high thermal stability make cation-exchanged A type zeolite a successful candidate for adsorption, ion exchange, and catalysis applications.
\end{abstract}

\section{Keywords}

Zeolite, Bactericidal, Adsorbent, Radioactive Recovery, Structure, LTA

\section{Introduction}

High porosity synthetic zeolites have been popular materials since their advent in late 1940s for catalysis, separation and purification applications, among others. Synthetic zeolites have a highly ordered structure and offer a unique advantage of narrow pore size distribution. Zeolites are known to possess valuable 
physiochemical properties such as adsorption, cation exchange, molecular sieving, and catalysis. They function on the basis of physisorption. The main driving force of the adsorption is the highly polar internal surface of the zeolite [1] [2] [3] [4]. This unique property distinguishes zeolites from other adsorbents and enables them to have an extremely high adsorption capacity. Maintaining a charged and large internal surface area, having a defined aperture size, presence of pores and cavities in the order of molecular dimensions $(0.3-1.0 \mathrm{~nm})$ plays a significant role in separation process, allowing or prohibiting the entrance of molecules to the pore system, leading to high separation factors [5] [6] [7].

Zeolites are mainly crystalline hydrated aluminosilicates with a pore size below $2 \mathrm{~nm}$ that are formed by tetrahedra primary building blocks of $\mathrm{SiO}_{4}$ and $\mathrm{AlO}_{4}$ linked by shared oxygen in a three-dimensional framework. The connection of $\mathrm{SiO}_{4}$ and $\mathrm{AlO}_{4}$ forms a variety of secondary structural units, which in turn are linked to form inorganic macromolecules with specific crystal structure. Their unique structure allows the water of crystallization to be removed, leaving a porous crystalline structure. These pores or cages have a high affinity to absorb water or other polar molecules. Molecules with large polarity or polarizability can be preferentially adsorbed under identical conditions. The application of zeolites as molecular sieve and catalyst depends on size and shape of their channel systems, as well as the nature and location of cations in framework [8] [9] [10].

Synthesis, characterization, and applications of zeolites have been investigated extensively during recent years. Zeolite $\mathrm{A}$ is a technologically important porous zeolite which is widely used for various separation and purification applications. Zeolite $\mathrm{A}$ in its as-synthesized form (molecular sieve 4A) has the unit cell formula, $\mathrm{Na}_{12}\left(\mathrm{AlO}_{2}\right)_{12} \cdot \mathrm{nH}_{2} \mathrm{O}$. Sodium ions can be exchanged by other calcium, silver, potassium or other metal ions to yield adsorbents with desired properties for different applications. The state, number and location of cations in framework have significant influence on adsorption properties of the zeolite [11] [12] [13]. The sorbate molecules must diffuse through an eight-ring window with an effective diameter of $0.42 \mathrm{~nm}$. The LTA framework is depicted in Figure 1 [2] [12].

Exchange of $\mathrm{Na}^{+}$ions in molecular sieve $\mathrm{Na}-\mathrm{A}$ with $\mathrm{Ag}^{+}$ions will reduce the pore opening further resulting in a drastic change in the adsorption properties. Calcium exchange gives Ca-A (5A) zeolite with vacant cationic sites and fully open eight-ring window [14] [15].

Microporous solids, because of their ability to interact with species both on their outer surface and throughout their inner porous network, have attracted considerable interest. The negative charge within the porous structure of the inorganic framework is compensated by the presence of cations. This gives the zeolites ability of ion-exchange that leads to incorporation of different metals in zeolite to generate desired catalytic properties. Exchangeable cations include lithium, cadmium, lead, zinc, copper, ammonia, silver, and protons [16] [17] [18]. 


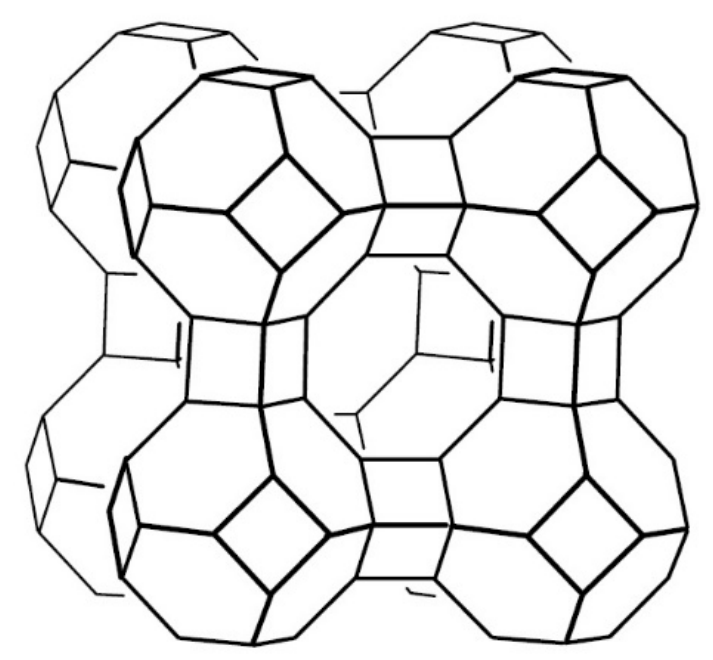

Figure 1. The LTA framework type.

The synthesis of A type zeolite involves preparation of four basic ingredients: silica, alumina, templates, and a source of seeds for nucleation enhancement. The gel that is formed by mixing appropriate proportion of these ingredients is crystallized under desired $\mathrm{pH}$ and temperature. Transition metals can be introduced into the framework of the zeolite in an ion exchange process to expand their pore structures, enhance their functionality and access new applications. The desired cation form of the zeolite can be mixed with a binder and extruded into required shape [19] [20] [21]. A wide variety of recipes for synthesis of A type zeolite from a range of source materials are available in open literature and the number of preparation methods are in the rise annually [20] [22]. The diversity of sources of ingredients, reaction and physical conditions leads into various production methods and final properties.

Zeolites have been found to be attractive reservoirs for silver ions. Silver-zeolite catalysts have attracted considerable interest because of their potential applications in nanoelectronics, optical filters, and nanocatalysis. In order to improve the microbial quality of water, silver loaded zeolites have been reported to be the most effective agents due to their non-selective effect on different functions of microbial cells [23] [24] [25] [26] [27]. The pore size of silver exchanged zeolite A is smaller than that of the starting zeolite Na-A. Therefore, it is expected that Ag-A zeolite displays better gas separation performance in the separation of hydrogen. Silver exchanged zeolites are used for reduction of $\mathrm{NO}_{\mathrm{x}}$ with propene. Absolute separation of ethylene/ethane mixture was achieved with the use of silver zeolite A [28] [29] [30] [31] [32]. This work was undertaken with the aim of practicing the synthesis of pure A type zeolite (LTA) and studying the surface and crystal structure of its cation exchanged forms.

\section{Results and Discussion}

It was observed that upon silver exchange in zeolite $\mathrm{A}$ and dehydration of product at $673 \mathrm{~K}$, the material underwent a change in color from white to red. The 
color change was reversible with respect to the adsorption and desorption of water molecules. The color change observed upon heating of Ag-A under vacuum has been attributed to the formation of $\mathrm{Ag}_{n}^{x+}$ clusters inside sodalite cavities of zeolite A. Silver ions migrate and undergo auto-reduction upon vacuum dehydration to form $\mathrm{Ag}^{0}$ that interacts with silver ions to form clusters. The reduction process in anhydrous conditions can be written as [25]:

$$
2 \mathrm{Ag}^{+}+\left(\mathrm{O}^{2-}\right)_{[\text {zeolite }]} \rightarrow 2 \mathrm{Ag}^{0}+1 / 2 \mathrm{O}_{2}+[]_{\text {zeolite }}
$$

[ ] represents oxygen vacancy in silver zeolite framework. An alternative explanation for the formation and interaction of $\mathrm{Ag}_{3}^{2+}$ clusters is based on Ligand to Metal Charge Transfer (LMCT) where electronic transition occurs between lone electron pairs of oxygen atoms in the zeolite framework to the empty $5 \mathrm{~s}$ orbital of $\mathrm{Ag}^{+}$ions [33].

The identification of the phases present was done using International Center for Diffraction Data Powder Diffraction File (ICDD-PDF 2.0). As can be seen in Table 1, cell type and space group were similar in both exchanged forms. Figure 2 shows the representative XRD pattern of $\mathrm{Ca}-\mathrm{A}$ and $\mathrm{Ag}$ - A zeolite samples. Both samples were identified as pure, single phase zeolite with no impurity phases present.

Table 1. Chemical composition (weight\%) of Kaolin.

\begin{tabular}{cccccccccc}
\hline Compound & $\mathrm{SiO}_{2}$ & $\mathrm{Al}_{2} \mathrm{O}_{3}$ & $\mathrm{Fe}_{2} \mathrm{O}_{3}$ & $\mathrm{MgO}$ & $\mathrm{CaO}$ & $\mathrm{TiO}_{2}$ & $\mathrm{~K}_{2} \mathrm{O}$ & $\mathrm{Na}_{2} \mathrm{O}$ & $\mathrm{LOI}^{*}\left(1050^{\circ} \mathrm{C}\right)$ \\
\hline Content (wt\%) & 44.62 & 38.23 & 1.62 & 0.27 & 0.96 & 0.24 & 1.87 & 0.65 & 11.56 \\
\hline
\end{tabular}

${ }^{\star}$ Loss on Ignition.

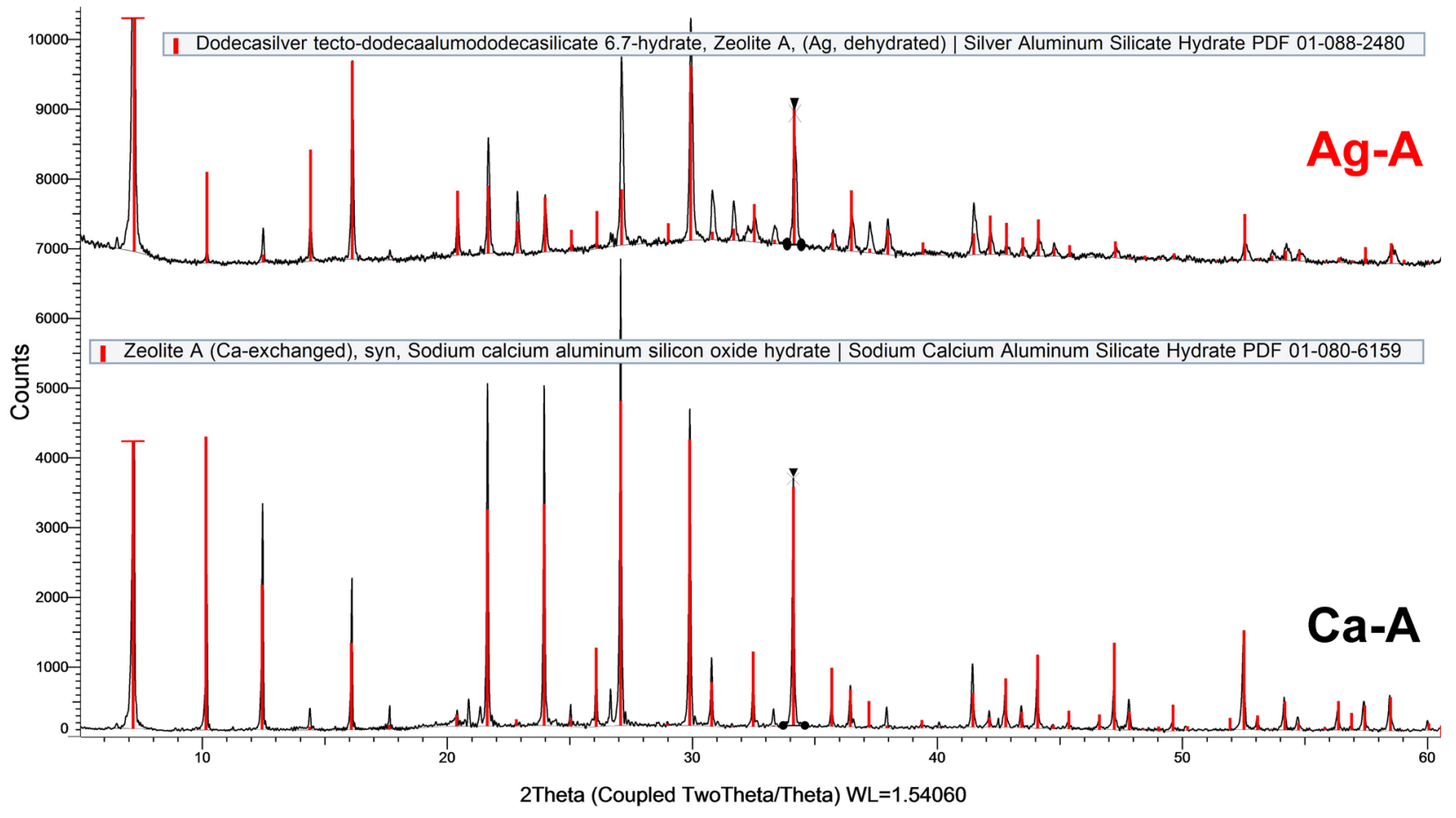

Figure 2. The XRD pattern of Ca- and Ag-exchanged zeolite A. 
SEM micrographs presented in Figure 3 for both Ca- and Ag-exchanged zeolite A revealed that crystal morphology of both samples were composed of flat and small particles which are closely similar in size and appearance. This result suggests that the exchange of sodium in the precursor with calcium and silver does not affect the appearance of the zeolites and shows that both samples retained their structure after calcium and silver absorption. The particle size of the resulting zeolites were in the range of $1.6-3.8$ and $0.9-2.3 \mu \mathrm{m}$ for the $\mathrm{Ca}-\mathrm{A}$ and Ag-A samples, respectively.

Semi-quantitative elemental analysis and confirmation of the exchange of sodium with calcium and silver was performed by energy dispersive X-ray spectroscopy (EDX). The elemental distribution of $\mathrm{Al}, \mathrm{Si}, \mathrm{O}, \mathrm{Ca}$, and $\mathrm{Ag}$ was studied using EDX mapping. Uniform distribution of $\mathrm{Ca}$ and $\mathrm{Ag}$ elements in their respective form of A type zeolite is an indication of successful exchange process. Presence of a peak at $3.0 \mathrm{KeV}$ in EDX spectrum confirmed existence of silver within the silver-zeolite. Silver ions can easily reach the nuclear content of bacteria. The high silver content of the silver exchanged zeolite A is desirable and has a high impact on the bactericidal activity of the zeolite [28] [29] [31] (Table 2).

Low intensity of sodium peak in exchanged forms is an indication of successful exchange of cations of the synthesized precursor. In conventional synthesis method, some of the sodium atoms are trapped in the sodalite cages of the zeolite. Elemental analysis of the product using EDX technique confirms the presence of sodium in both exchanged types, as can be seen in Table 3 .

Table 2. Results of XRD analysis of Ca- and Ag-exchanged zeolite A.

\begin{tabular}{cccccc}
\hline & $\begin{array}{c}\text { Cell } \\
\text { system }\end{array}$ & $\begin{array}{c}\text { Framework } \\
\text { type }\end{array}$ & $\begin{array}{c}\text { Crystallite } \\
\text { size }\end{array}$ & Crystallinity & Chemical composition \\
\hline Ca-A & Cubic & LTA & $108.2 \mathrm{~nm}$ & 64.3 & $\mathrm{Na}_{7.9} \mathrm{Ca}_{2.4}\left(\mathrm{Al}_{11.8} \mathrm{Si}_{12.2} \mathrm{O}_{48}\right)\left(\mathrm{H}_{2} \mathrm{O}\right)_{34.8}$ \\
$\mathrm{Ag}-\mathrm{A}$ & Cubic & LTA & $57.6 \mathrm{~nm}$ & 59.4 & $\mathrm{Ag}_{12}\left(\mathrm{Al}_{12} \mathrm{Si}_{12} \mathrm{O}_{48}\right)\left(\mathrm{H}_{2} \mathrm{O}\right)_{6.7}$ \\
\hline
\end{tabular}

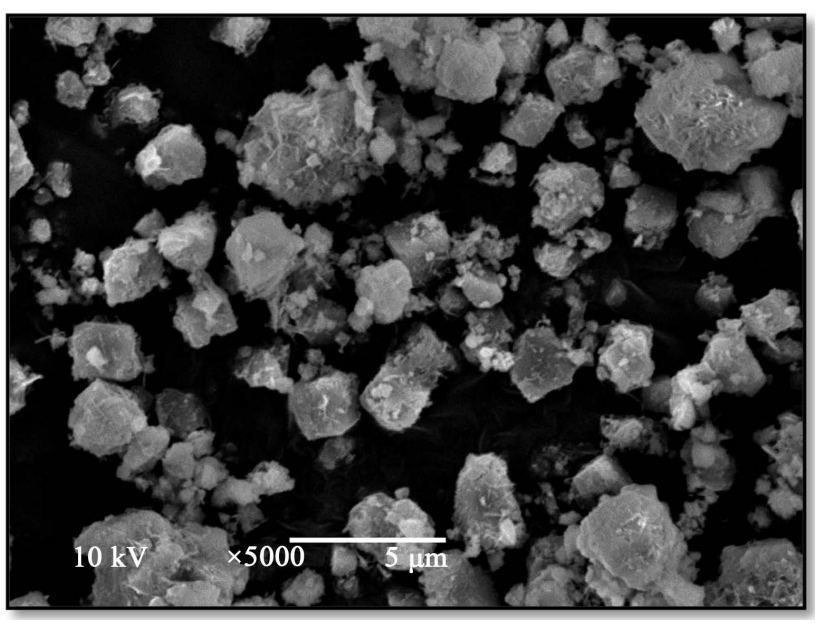

(a)

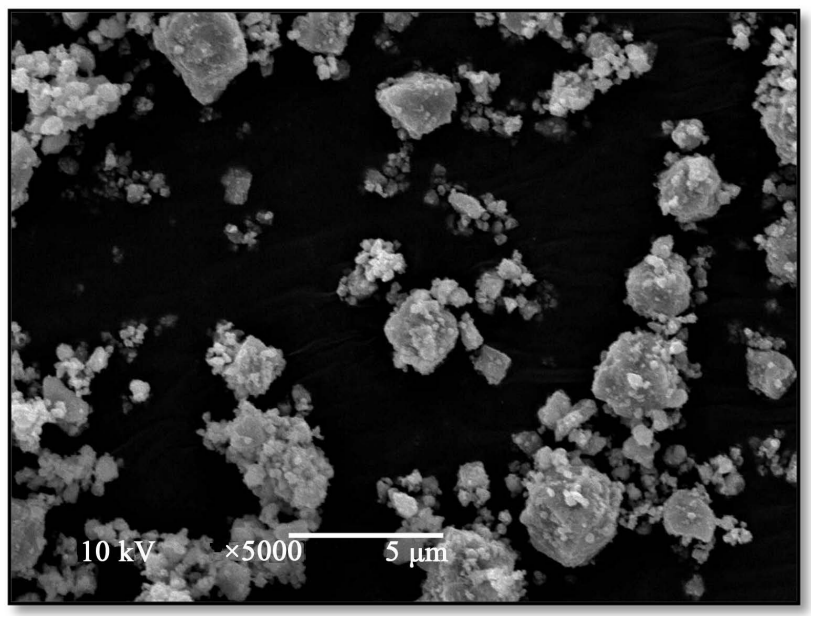

(b)

Figure 3. SEM images of (a) Ca-A and (b) Ag-A, zeolite crystals. 
Table 3. Elemental composition of Ca- and Ag-exchanged zeolite A.

\begin{tabular}{cccccc}
\hline Zeolites & $\mathrm{Al}$ & $\mathrm{Si}$ & $\mathrm{Ca}$ & $\mathrm{Ag}$ & $\mathrm{Na}$ \\
\hline $\mathrm{Ca}-\mathrm{A}$ & 34.79 & 43.19 & 14.98 & - & 6.86 \\
$\mathrm{Ag}-\mathrm{A}$ & 17.76 & 26.55 & - & 54.62 & 1.07 \\
\hline
\end{tabular}

XRD and EDX analytical techniques provided ample evidence of the synthesis of desired zeolite. As can be seen in Figure 4, sodium, aluminum and silicon were distributed relatively uniform. Oxygen was abundant in highly crystalline areas while calcium was spread in amorphous aggregates.

Figure 5 exhibits the $\mathrm{N}_{2}$ adsorption and desorption isotherms at $-195.9^{\circ} \mathrm{C}$ for zeolites $\mathrm{Ca}-\mathrm{A}$ and Ag-A. According to an updated classification of physisorption isotherms, the isotherm is of type $\mathrm{I}(\mathrm{a})$ which is seen in microporous solids having mainly narrow micropores of width $<1 \mathrm{~nm}$. The steep uptake at very low $\mathrm{p} / \mathrm{p}^{0}$ is due to enhanced adsorbent-adsorptive interactions in narrow micropores. The hysteresis loop seen in the multilayer range of both samples, are associated with capillary condensation in mesopore structure as a result of metastability of the adsorbed multilayer in an open-ended pore. The narrow and steep hysteresis loop is a clear sign of delayed condensation associated with pore blocking. The limiting value of amount adsorbed is governed by the accessible micropore volume rather than by internal surface area. Desorption branch is used for mesopore size analysis, but this method is now considered to be questionable since the desorption path may be dependent on network percolation effect or pore diameter variation along single channels [34] [35].

Table 4 gives surface area, pore volume, and average pore diameter for the Ca- and Ag- exchanged zeolite A. Micropore area and volume were calculated based on $\mathrm{t}$-plot method and the total pore volume was calculated at $p / p_{0}=0.99$. Larger exchanged cation in Ag-A decreased the micropore volume. While XRD analysis confirmed that the type A framework in the resulting Ca- and Ag-exchanged zeolites maintained unchanged, $\alpha$-site occupation of silver ions tend to decrease the aperture size of the zeolite and reduction of accessible path for $\mathrm{N}_{2}$ molecules which in turn limits the access to channels. The smaller specific area seen in silver exchanged zeolite A can be attributed to the blocking of the channels [36].

CEC values of the $\mathrm{Ca}-\mathrm{A}$ and $\mathrm{Ag}-\mathrm{A}$ are presented in Table 3. Both synthesized zeolites gave very high exchange capacity. The high CEC values makes these materials interesting for industrial applications since natural zeolites usually show lower exchange capacity in the range of $2.2-5.2 \mathrm{meq} / \mathrm{g}$ [37] [38] [39]. High CEC zeolites are desirable in the ammonia separation from water [40].

$\mathrm{X}$-ray photoelectron spectroscopy show a negative shift in binding energy of calcium and silver in respective exchanged forms of type A zeolite. The binding energy values of $\mathrm{Ag}-\mathrm{A}$ are close to those of $\mathrm{AgF}$ and $\mathrm{AgF}_{2}$ and this fact indicates that silver is present as $\mathrm{Ag}^{+}$in silver-exchanged zeolite A [41]. An XPS survey scan of Ca-A and Ag-A molecular sieves showing $\mathrm{Na}_{2 \mathrm{~s}} \mathrm{Al}_{2 \mathrm{p}}, \mathrm{Si}_{2 \mathrm{p}}, \mathrm{Al}_{2 \mathrm{~s}}, \mathrm{Si}_{2 \mathrm{~s}}, \mathrm{Ca}_{2 \mathrm{p}}$, 


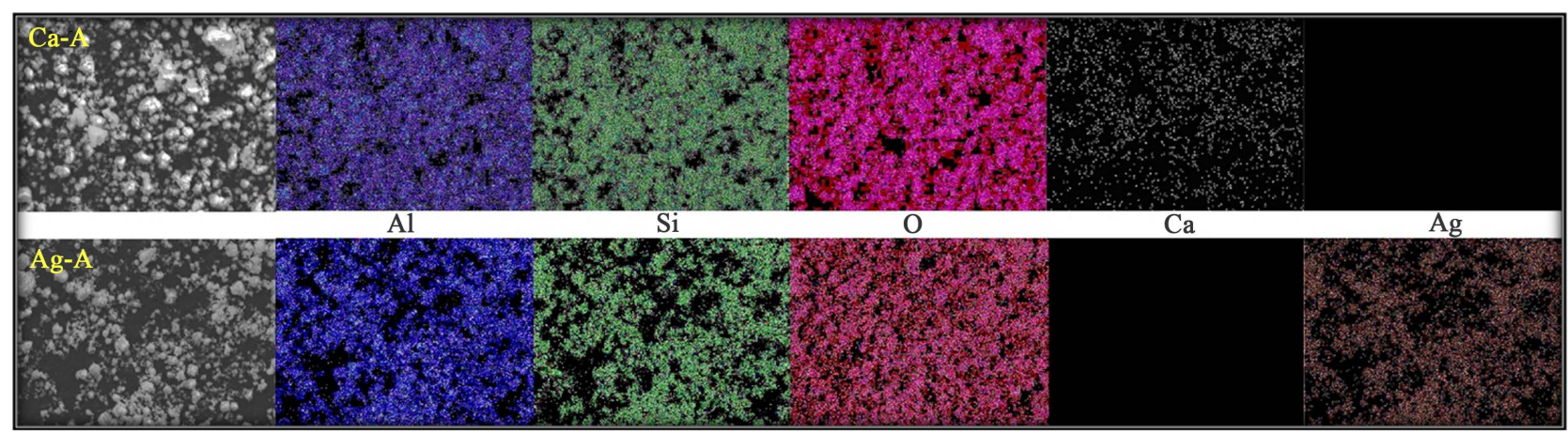

Figure 4. EDX mapping of micro-particles of top) $\mathrm{Ca}-\mathrm{A}$ and, bottom) Ag-A, and corresponding elemental mapping of $\mathrm{Al}$, Si, $\mathrm{O}$, $\mathrm{Ca}$, and $\mathrm{Ag}$.

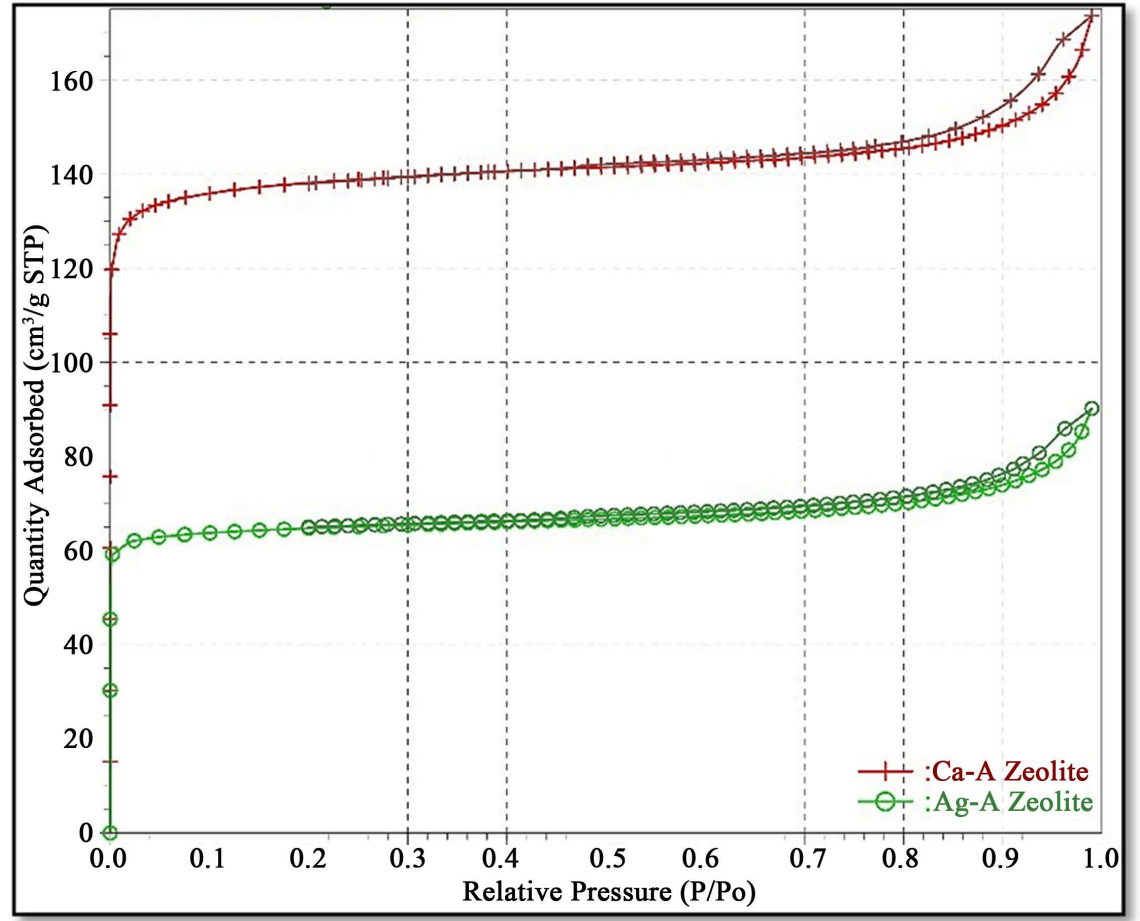

Figure 5. Nitrogen adsorption isotherms of zeolite Ca-A and Ag-A at $-196.15^{\circ} \mathrm{C}$.

Table 4. Surface area and exchange capacity of Ca- and Ag-exchanged zeolite A.

\begin{tabular}{|c|c|c|c|c|c|c|c|}
\hline \multirow{2}{*}{ Zeolites } & \multicolumn{2}{|c|}{$\begin{array}{l}\text { Surface area } \\
\qquad\left(\mathrm{m}^{2} / \mathrm{g}\right)\end{array}$} & \multicolumn{2}{|c|}{$\begin{array}{l}\text { Pore volume } \\
\qquad\left(\mathrm{cm}^{3} / \mathrm{g}\right)\end{array}$} & \multicolumn{2}{|c|}{$\begin{array}{l}\text { BJH average pore } \\
\text { diameter }(\mathrm{nm})\end{array}$} & \multirow{2}{*}{$\begin{array}{c}\text { CEC } \\
(\mathrm{meq} / \mathrm{g})\end{array}$} \\
\hline & BET & $\begin{array}{c}\text { Micropore } \\
\text { area }^{\text {a }}\end{array}$ & $\begin{array}{l}\text { Total pore } \\
\text { volume }\end{array}$ & $\begin{array}{l}\text { Micropore } \\
\text { volume }^{\mathrm{a}}\end{array}$ & Adsorption & Desorption & \\
\hline $\mathrm{Ca}-\mathrm{A}$ & 451.0 & 417.9 & 0.27 & 0.200 & 6.06 & 9.9 & 4.54 \\
\hline Ag-A & 207.6 & 190.7 & 0.14 & 0.092 & 8.11 & 11.4 & 3.57 \\
\hline
\end{tabular}

${ }^{\mathrm{a}}$ calculated based on t-plot method; ${ }^{\mathrm{b}}$ Total pore volume at $p / p_{0}=0.96$.

$\mathrm{Ag}_{3 \mathrm{~d}}, \mathrm{Ca}_{2 \mathrm{~s}}$, and $\mathrm{O}_{1 \mathrm{~s}}$ photoelectron lines in Figure 6 shows the fully scanned spectra of Na-A and Ag-A zeolites in the range of $0-1000 \mathrm{eV}$. Quantitative measurement of $\mathrm{Na}$ was performed using $\mathrm{Na}_{2 \mathrm{~s}}$ line. Aluminum and silicon were 


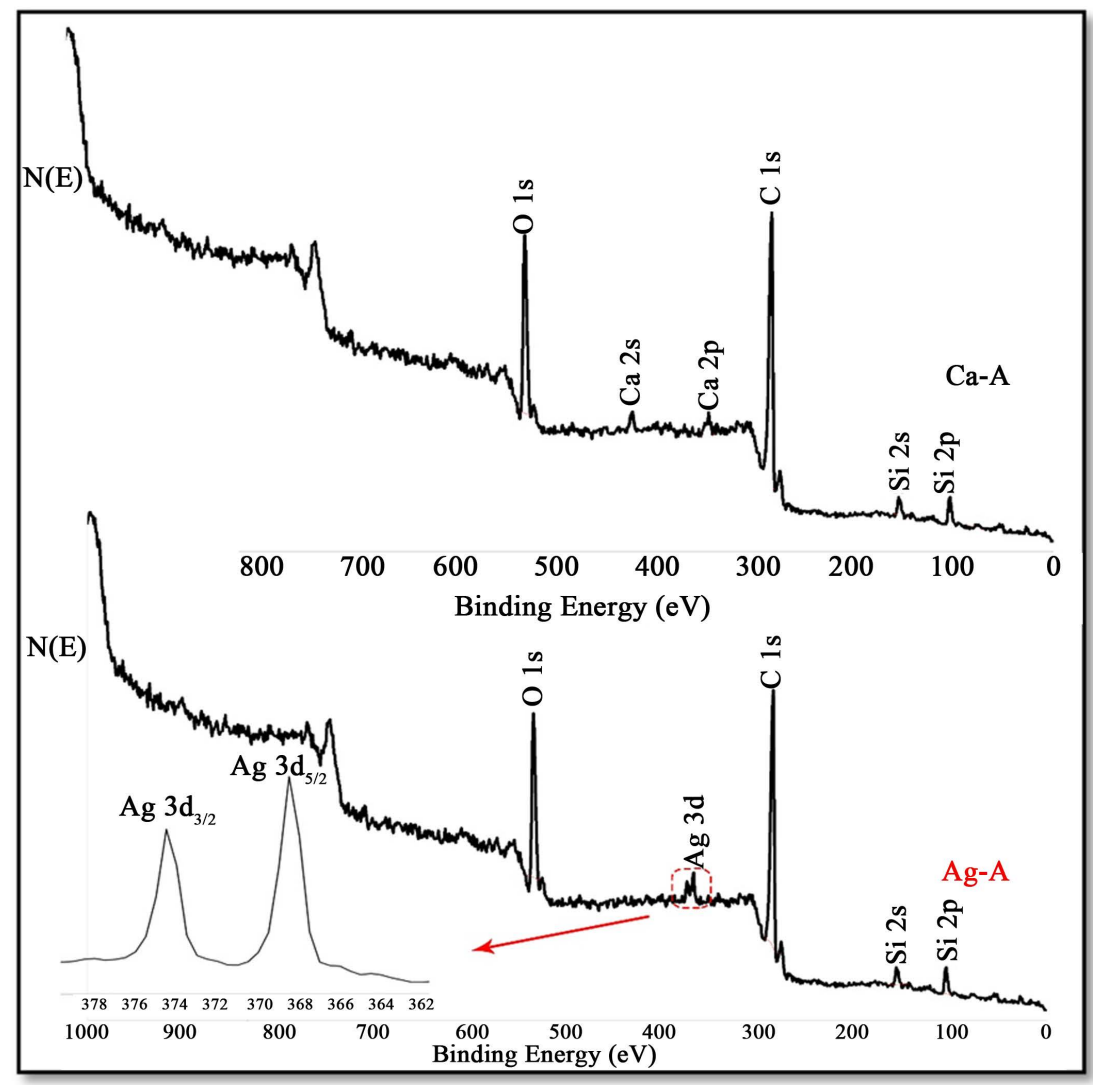

Figure 6. XPS analysis of Ca-A and Ag-A zeolites.

measured using integrated photoelectron line intensities of $\mathrm{Al}_{2 \mathrm{~s}}$ and $\mathrm{Si}_{2 \mathrm{p}}$ lines. The shift in the binding energy of $\mathrm{Si}_{2 \mathrm{p}}-\mathrm{Al}_{2 \mathrm{~s}}$ in Ca-A zeolite was found to be 17.1 eV.

The FTIR spectrum for the Ca-A and Ag-A zeolite samples in the range of $4000-600 \mathrm{~cm}^{-1}$ is given in Figure 7. The absorption bands in Figure 7 agree well with the bands $\left(554,664\right.$, and $\left.1000 \mathrm{~cm}^{-1}\right)$ reported by Breck [8]. FTIR spectra show a sharp peak with high intensity at 990 and $971.5 \mathrm{~cm}^{-1}$ for the Ca-A and Ag-A samples respectively. This vibration is assigned to the $\mathrm{T}-\mathrm{O}-\mathrm{T}(\mathrm{T}=\mathrm{Al}$ or $\mathrm{Si}$ ) asymmetric stretching vibration. The peak detected at 672 and $666 \mathrm{~cm}^{-1}$ which can be assigned to the $\mathrm{T}-\mathrm{O}-\mathrm{T}$ symmetric stretching has less intensity compared to the asymmetric stretching of T-O-T band in Ca-A and Ag-A, respectively. This is likely as the probability of symmetric stretching of $\mathrm{T}-\mathrm{O}$ bond is less compared to asymmetric stretching and bending. In zeolites, the water molecules are associated with cations or framework oxygen. The association of the water molecules with the cation or framework oxygen ions of a zeolite is dependent upon the openness of the structure. The broad band observed at 3360 and $3385 \mathrm{~cm}^{-1}$ is characteristic of hydrogen bond between the oxygen atoms of the framework and $\mathrm{OH}$ in water [42] [43] [44] [45].

Thermogravimetric analysis was carried out to further investigate the stability of the water molecules in the zeolite framework and the results are shown in Figure 8. A minimum at $175^{\circ} \mathrm{C}$ and $195^{\circ} \mathrm{C}$ in the derivative TGA curves of the 


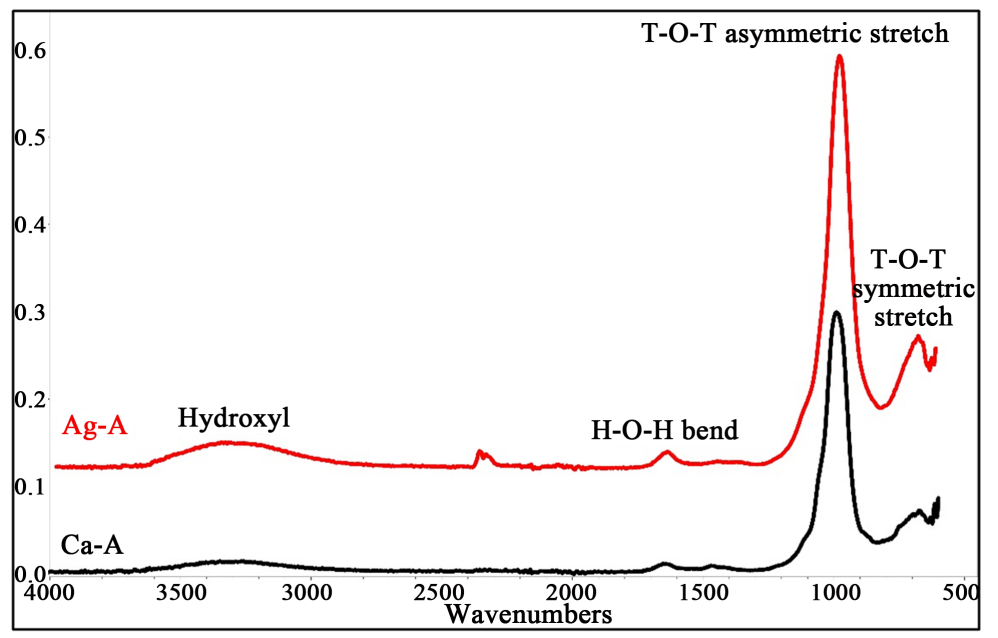

Figure 7. FTIR spectra of Ca-A and Ag-A zeolite.
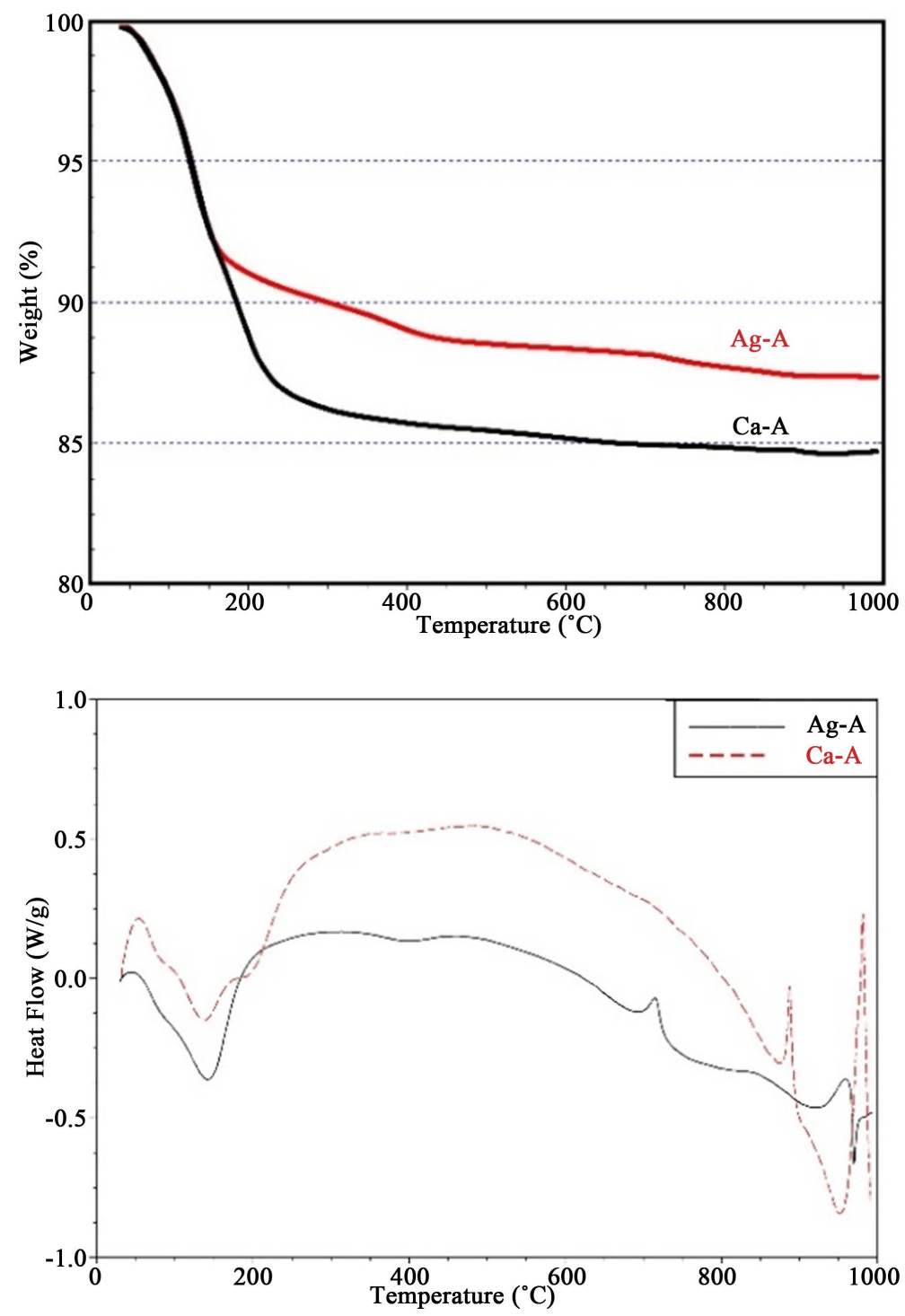

Figure 8. Weight loss and Heat Flow diagram of Ca-A and Ag-A zeolite. 
Ag-A and Ca-A corresponds to removal of loosely held moisture. Ca-A looses $16.0 \%$ of its weight which is twice as much as what Ag-A lost (8.2\%). The enthalpy of heat flow peak at $742^{\circ} \mathrm{C}$ is $59 \mathrm{~J} / \mathrm{g}$ for the silver-exchanged zeolite while heat flow graph of $\mathrm{Ca}-\mathrm{A}$ shows a peak at $872^{\circ} \mathrm{C}$ with an enthalpy of $125 \mathrm{~J} / \mathrm{g}$. It can be concluded that water molecules are more strongly bound in the $\mathrm{Ca}-\mathrm{A}$ zeolite compared to Ag-A zeolite.

\section{Experimental Details}

\subsection{Materials and Chemicals}

The precursor Zeolite A was metakaolin with an average particle size below 45 micron. The metakaolin was prepared by dihydroxylation of kaolin at $800^{\circ} \mathrm{C}$ for $2 \mathrm{hr}$. Additional silica and alumina was added to adjust mole ratio of $\mathrm{SiO}_{2}, \mathrm{Al}_{2} \mathrm{O}_{3}$ and $\mathrm{Na}_{2} \mathrm{O}$ in the following range [2] [13]:

$$
\begin{aligned}
& \mathrm{SiO}_{2} / \mathrm{Al}_{2} \mathrm{O}_{3}: 1.6-2.4 \\
& \mathrm{Na}_{2} \mathrm{O} / \mathrm{SiO}_{2}: 1.8-3.8 \\
& \mathrm{H}_{2} \mathrm{O} / \mathrm{Na}_{2} \mathrm{O}: 30-50
\end{aligned}
$$

Changes in the mole ratio of $\mathrm{Na}_{2} \mathrm{O} / \mathrm{SiO}_{2}$ do not affect in the nucleation of zeolite [9] [13]. In this study, the $\mathrm{Na}_{2} \mathrm{O} / \mathrm{SiO}_{2}$ and $\mathrm{H}_{2} \mathrm{O} / \mathrm{Na}_{2} \mathrm{O}$ mole ratios were conveniently chosen as 2.0 and 50 , respectively. Metakaolin was gradually added to sodium hydroxide solution. The reaction vessel was agitated at $90^{\circ} \mathrm{C}$ and was stirred until formation of gel within $3 \mathrm{hr}$., then stopped to allow nucleation at room temperature for $48 \mathrm{hr}$. Crystallization at $90^{\circ} \mathrm{C}$ resulted in precipitation of $\mathrm{Na}-\mathrm{A}$ zeolite. The product was washed with $\mathrm{DI}$ water till $\mathrm{pH}$ reached below 10 [2] [13].

Calcium-and silver-exchanged zeolite A were prepared by ion-exchange of product using calcium and silver salts. The total capacity of products to hold exchangeable cations was measured. The effect of exchange on crystal structure, morphology, mineral composition, and textural properties was studied. X-Ray Photoelectron Spectroscopy (XPS) was employed to determine the oxidation state and binding energies of calcium and silver. Since XPS is extremely surface sensitive, this approach provides valuable insight into the catalytic properties of exchanged forms of A type zeolite.

The calcium and silver ions were introduced to the zeolite in an exchange process. Analytical grade calcium chloride $\left(\mathrm{CaCl}_{2}\right)$ and silver nitrate $\left(\mathrm{AgNO}_{3}\right)$ were used to prepare 0.1 aqueous solutions which were then refluxed with zeolite with a solid/liquid ratio $1 \mathrm{~g}: 100 \mathrm{ml}$. The silver exchange process was carried out in darkroom. The exchange process was performed at $80^{\circ} \mathrm{C}$ for $6 \mathrm{~h}$. Exchange process can proceed even in ambient temperature due to higher affinity of both $\mathrm{Ca}^{2+}$ and $\mathrm{Ag}^{+}$ions toward exchange sites over $\mathrm{Na}^{+}$ions. Calcium- and silver-exchanged zeolites were separated by simple filtration, washed with distilled water and isopropanol, dehydrated at $400^{\circ} \mathrm{C}$ for $12 \mathrm{~h}$ under $10^{-6}$ mbar before characterization and were noted as $\mathrm{Ca}-\mathrm{A}$ and $\mathrm{Ag}-\mathrm{A}$, respectively. The Cation Exchange Capacity (CEC) of the samples was determined to measure the total 
capacity of products to hold exchangeable cations. Zeolites having high CEC are useful in the ammonia removal from water.

\subsection{Characterization Method}

$\mathrm{Ca}-\mathrm{A}$ and $\mathrm{Ag}-\mathrm{A}$ Samples were subject to instrumental characterization using X-Ray Diffraction (XRD), Scanning Electron Microscopy (SEM), and Energy Dispersive X-ray (EDX) techniques. X-ray diffraction (XRD) analysis were performed using an Advance Bruker-D8 Discover diffractometer $\left(\mathrm{K}_{\mathrm{a} 1}=1.5406 \AA\right.$, $2 \theta$ range from $5^{\circ}$ to $60^{\circ}$ ). The detector was LYNXEYE-XE (operating at $40.0 \mathrm{kV}$ and $40.0 \mathrm{~mA}$ ). The mineral phases were identified using EVA crystallographic software integrated with Powder Diffraction File (PDF) database. Scanning Electron Microscope (SEM) and Energy Dispersive X-ray Spectroscopy (EDX) were performed on the powders using a JEOL JSM-6460LV electron microscope. The materials were dispersed onto carbon tabs and coated with a fine layer of gold using a sputter coater.

Nitrogen adsorption measurements were carried out to investigate the textural properties using an ASAP 2020 Micromeritics specific surface analyzer. The specific surface area of the zeolites was determined based on the shape of the vapor nitrogen adsorption/desorption isotherms in $-196.15^{\circ} \mathrm{C}$ in a relative pressure range from about $10^{-6}$ to 0.99 . Before the measurements, the samples were outgassed in two phases. Evacuation phase started with a temperature ramp rate of $10^{\circ} \mathrm{C} / \mathrm{min}$ to target temperature of $90^{\circ} \mathrm{C}$. Evacuation rate was set to $50 \mathrm{mmHg} / \mathrm{s}$ followed by unrestricted evacuation below $5.00 \mathrm{mmHg}$ down to a vacuum set point of $500 \mu \mathrm{mHg}$ in $120 \mathrm{~min}$. The heating phase involved a $10^{\circ} \mathrm{C} / \mathrm{min}$ ramp to a target temperature of $350^{\circ} \mathrm{C}$. Hold time and pressure were $600 \mathrm{~min}$ and 20 $\mathrm{mmHg}$ respectively. The water and impurity gas molecules adsorbed in the pores of zeolites can be re moved, but the structural water molecules still exist. The water contents of the samples were determined using a TA Instruments, SDT2960 thermo-gravimetric analyzer.

X-ray Photoelectron Spectroscopy (XPS) or ESCA (Electron Spectroscopy for Chemical Analysis) is one of the most widely used surface analysis techniques that provides valuable chemical state information. XPS studies were carried out using a Perkin Elmer PHI 5440 system equipped with a monochromated Mg-Ka radiation source $(1253.6 \mathrm{eV})$ and hemispherical analyzer. Finely powdered zeolite samples were mounted on a stub in the preparation chamber and kept under vacuum for $24 \mathrm{~h}$ before being transferred to the analysis chamber. The vacuum in the analysis chamber was maintained below $3 \times 10^{-8} \mathrm{mbar}$ during the analysis. The $\mathrm{Si}_{2 \mathrm{p}}$ line at $103.0 \mathrm{eV}$ was used as internal reference for correction of charging effect. Binding energies for $\mathrm{Ca} 2 \mathrm{p}$ and $\mathrm{Ag} 3 \mathrm{~d}$ electrons were determined by scanning the range of $430-442 \mathrm{eV}$ and $363-377 \mathrm{eV}$ in calcium and silver exchanged zeolites with a step size of $0.05 \mathrm{eV}$. The FTIR was done ranging wavenumber from 4000 to 600 by transmittance using $\mathrm{KBr}$ (Bruker Vector 22). The Cation Exchange Capacity (CEC) of the zeolites precursor Na-A zeolite was measured by the $\mathrm{BaCl}_{2}$ compulsive exchange method [32]. 


\section{Conclusion}

In the present work, synthesis and characterization of two exchanged forms of zeolite A were studied. Kaolin was converted to type A zeolite and the exchange products were characterized using x-ray diffraction, scanning electron microscopy, energy dispersive spectroscopy, and thermogravimetric analysis. Textural properties and porosity were also investigated using BET method. The results revealed that following the exchange process with calcium and silver, the cell system, space group and framework maintained unchanged as revealed by XRD analysis, while the aperture of the zeolite channels was covered in case of larger cation occupying $\alpha$-site in zeolite structure. XPS studies of calcium- and silverexchanged zeolite A showed that the observed surface atomic composition has a significant difference from the stoichiometric composition with respect to the cation concentrations and confirmed the presence of highly dispersed cationic calcium and silver species at exchange sites. Successful substitution of calcium with sodium in framework of the zeolite allows the use of the synthetic zeolite A as builders in detergents for removal of calcium ions from water. Thermogravimetric analysis showed a larger amount of strongly bound water molecules in calcium exchanged form. The presence of micropores, as well as high specific surface area and CEC suggests potential applications in adsorption and ion exchange applications. Further optimization of the mixture composition and reaction conditions can improve crystallinity of the pure zeolites synthesized.

Modification of adsorption characteristics by tailoring crystal structure and pore architecture of zeolites results yields better control in separation and adsorption applications. Recovery of radioactive materials is a particular application of silver exchanged A type zeolite. Silver exchanged LTA can be proposed as a low cost bactericidal material. The inhibition of E. coli and $S$. aureus bacteria using silver modified natural zeolite has been proved successful. Atomic resolution study of dispersion and condition of active elements on surface results in better understanding of surface affinity of silver zeolites toward different species.

\section{References}

[1] Cundy, C.S. and Cox, P.A. (2003) The Hydrothermal Synthesis of Zeolites: History and Development from the Earliest Days to the Present Time. Chemical Reviews, 103, 663-702. https://doi.org/10.1021/cr020060i

[2] Valtchev, V. and Tosheva, L. (2013) Porous Nanosized Particles: Preparation, Properties, and Applications. Chemical Reviews, 113, 6734-6760.

https://doi.org/10.1021/cr300439k

[3] Lin, C., Dambrowitz, K.A. and Kuznicki, S.M. (2012) Evolving Applications of Zeolite Molecular Sieves. The Canadian Journal of Chemical Engineering, 90, 207-216. https://doi.org/10.1002/cjce.20667

[4] Barthomeuf, D. (1996) Basic Zeolites: Characterization and Uses in Adsorption and Catalysis. Catalysis Reviews, 38, 521-612. https://doi.org/10.1080/01614949608006465

[5] Olsbye, U., Svelle, S., Bjørgen, M., Beato, P., Janssens, T.V.W., Joensen, F., Bordiga, 
S. and Lillerud, K.P. (2012) Conversion of Methanol to Hydrocarbons: How Zeolite Cavity and Pore Size Controls Product Electivity. Angewandte Chemie International Edition, 51, 5810-5831. https://doi.org/10.1002/anie.201103657

[6] Shah, D., Kissick, K., Ghorpade, A., Hannah, R. and Bhattacharyya, D. (2000) Pervaporation of Alcohol-Water and Dimethylformamide-Water Mixtures Using Hydrophilic Zeolite NaA Membranes: Mechanisms and Experimental Results. Journal of Membrane Science, 179, 185-205. https://doi.org/10.1016/S0376-7388(00)00515-9

[7] Caro, J., Noack, M., Kölsch, P. and Schäfer, R. (2000) Zeolite Membranes-State of Their Development and Perspective. Microporous and Mesoporous Materials, 38, 3-24. https://doi.org/10.1016/S1387-1811(99)00295-4

[8] Rollmann, L.D., Valyocsik, E.W. and Shannon, R.D. (2007) Zeolite Molecular Sieves. Inorganic Syntheses, 22, 61-68. https://doi.org/10.1002/9780470132531.ch12

[9] Rabo, J.A. (1976) Zeolite Chemistry and Catalysis. Amer Chemical Society, 171, Washington DC.

[10] Davis, M.E. and Raul, R.F. (1992) Zeolite and Molecular Sieve Synthesis. Chemistry of Materials, 4, 756-768. https://doi.org/10.1021/cm00022a005

[11] Watanabe, K., Austin, N. and Stapleton, M.R. (1995) Investigation of the Air Separation Properties of Zeolites Types A, X and Y by Monte Carlo Simulations. Molecular Simulation, 15, 197-221. https://doi.org/10.1080/08927029508022335

[12] Sato, K., Aoki, K., Sugimoto, K., Izumi, K., Inoue, S., Saito, J., Ikeda, S. and Nakane, T. (2008) Dehydrating Performance of Commercial LTA Zeolite Membranes and Application to Fuel Grade Bio-Ethanol Production by Hybrid Distillation/Vapor Permeation Process. Microporous and Mesoporous Materials, 115, 184-188. https://doi.org/10.1016/j.micromeso.2007.10.053

[13] Shams, K. and Mirmohammadi, S.J. (2007) Preparation of 5A Zeolite Monolith Granular Extrudates Using Kaolin: Investigation of the Effect of Binder on Sieving/Adsorption Properties Using a Mixture of Linear and Branched Paraffin Hydrocarbons. Microporous and Mesoporous Materials, 106, 268-277. https://doi.org/10.1016/j.micromeso.2007.03.007

[14] Wang, Z., Ge, Q., Shao, J. and Yan, Y. (2009) High Performance Zeolite LTA Pervaporation Membranes on Ceramic Hollow Fibers by Dipcoating-Wiping Seed Deposition. Journal of the American Chemical Society, 131, 6910-6911. https://doi.org/10.1021/ja901626d

[15] Corma, A. (1997) From Microporous to Mesoporous Molecular Sieve Materials and Their Use in Catalysis. Chemical Reviews, 97, 2373-2420.

https://doi.org/10.1021/cr960406n

[16] Weitkamp, J. (2000) Zeolites and Catalysis. Solid State Ionics, 131, 175-188. https://doi.org/10.1016/S0167-2738(00)00632-9

[17] Corma, A. (2003) State of the Art and Future Challenges of Zeolites as Catalysts. Journal of Catalysis, 216, 298-312. https://doi.org/10.1016/S0021-9517(02)00132-X

[18] Zhu, G., Qiu, S., Yu, J., Sakamoto, Y., Xiao, F., Xu, R. and Terasaki, O. (1998) Synthesis and Characterization of High-Quality Zeolite LTA and FAU Single Nanocrystals. Chemistry of Materials, 10, 1483-1486. https://doi.org/10.1021/cm980061k

[19] Hargreaves, J.S.J. and Munnoch, A.L. (2013) A Survey of the Influence of Binders in Zeolite Catalysis. Catalysis Science \& Technology, 3, 1165-1171. https://doi.org/10.1039/c3cy20866d

[20] Cundy, C.S. and Cox, P.A. (2005) The Hydrothermal Synthesis of Zeolites: Precur- 
sors, Intermediates and Reaction Mechanism. Microporous and Mesoporous Materials, 82, 1-78. https://doi.org/10.1016/j.micromeso.2005.02.016

[21] Rakoczy, R.A. and Traa, Y. (2003) Nanocrystalline Zeolite A: Synthesis, Ion Exchange and Dealumination. Microporous and Mesoporous Materials, 60, 69-78. https://doi.org/10.1016/S1387-1811(03)00318-4

[22] Robson, H. (2001) Verified Synthesis of Zeolitic Materials. Gulf Professional Publishing, Huston.

[23] Lalueza, P., Monzón, M., Arruebo, M. and Santamaría, J. (2011) Bactericidal Effects of Different Silver-Containing Materials. Materials Research Bulletin, 46, 2070 2076. https://doi.org/10.1016/j.materresbull.2011.06.041

[24] Sebastian, J. and Jasra, R.V. (2005) Sorption of Nitrogen, Oxygen, and Argon in Silver-Exchanged Zeolites. Industrial \& Engineering Chemistry Research, 44, 80148024. https://doi.org/10.1021/ie050442p

[25] Mayoral, A., Carey, T., Anderson, P.A., Lubk, A. and Diaz, I. (2011) Atomic Resolution Analysis of Silver Ion-Exchanged Zeolite A. Angewandte Chemie International Edition, 50, 11230-11233. https://doi.org/10.1002/anie.201105450

[26] Ferreira, L., Fonseca, A.M., Botelho, G., Almeida-Aguiar, C. and Neves, I.C. (2012) Antimicrobial Activity of Faujasite Zeolites Doped with Silver. Microporous and Mesoporous Materials, 160, 126-132. https://doi.org/10.1016/j.micromeso.2012.05.006

[27] Top, A. and Ülkü, S. (2004) Silver, Zinc, and Copper Exchange in a Na-Clinoptilolite and Resulting Effect on Antibacterial Activity. Applied Clay Science, 27, 13-19. https://doi.org/10.1016/j.clay.2003.12.002

[28] Maillard, J.Y. and Hartemann, P. (2013) Silver as an Antimicrobial: Facts and Gaps in Knowledge. Critical Reviews in Microbiology, 39, 373-383. https://doi.org/10.3109/1040841X.2012.713323

[29] Zhou, Y., Deng, Y., He, P., Dong, F., Xia, Y. and He, Y. (2014) Antibacterial Zeolite with a High Silver-Loading Content and Excellent Antibacterial Performance. RsC Advances, 4, 5283-5288. https://doi.org/10.1039/c3ra44750b

[30] Aguado, S., Bergeret, G., Daniel, C. and Farrusseng, D. (2012) Absolute Molecular Sieve Separation of Ethylene/Ethane Mixtures with Silver Zeolite A. Journal of the American Chemical Society, 134, 14635-14637. https://doi.org/10.1021/ja305663k

[31] Seijger, G.B.F., Niekerk, V.K., Krishna, K., Calis, H.P.A., Van Bekkum, H. and Van den Bleek, C.M. (2003) Screening of Silver and Cerium Exchanged Zeolite Catalysts for the Lean Burn Reduction of NOx with Propene. Applied Catalysis B: Environmental, 40, 31-42. https://doi.org/10.1016/S0926-3373(02)00128-5

[32] Gillman, G.P. and Sumpter, E.A. (1986) Modification to the Compulsive Exchange Method for Measuring Exchange Characteristics of Soils. Soil Research, 24, 61-66. https://doi.org/10.1071/SR9860061

[33] Seifert, R., Kunzmann, A. and Calzaferri, G. (1998) The Yellow Color of SilverContaining Zeolite A. Angewandte Chemie International Edition, 37, 1521-1524. https://doi.org/10.1002/(SICI)1521-3773(19980619)37:11<1521::AID-ANIE1521>3. $0 . \mathrm{CO} ; 2-\mathrm{V}$

[34] Sing, K. (2001) The Use of Nitrogen Adsorption for the Characterisation of Porous Materials. Colloids and Surfaces A: Physicochemical and Engineering Aspects, 187, 3-9. https://doi.org/10.1016/S0927-7757(01)00612-4

[35] Thommes, M. (2010) Physical Adsorption Characterization of Nanoporous Materials. Chemie Ingenieur Technik, 82, 1059-1073. 
https://doi.org/10.1002/cite.201000064

[36] Hernandez, M.A., Rojas, F. and Lara, V.H. (2000) Nitrogen-Sorption Characterization of the Microporous Structure of Clinoptilolite-Type Zeolites. Journal of Porous Materials, 7, 443-454. https://doi.org/10.1023/A:1009662408173

[37] Erdem, E., Karapinar, N. and Donat, R. (2004) The Removal of Heavy Metal Cations by Natural Zeolites. Journal of Colloid and Interface Science, 280, 309-314. https://doi.org/10.1016/j.jcis.2004.08.028

[38] Mondale, K.D., Carland, R.M. and Aplan, F.F. (1995) The Comparative Ion Exchange Capacities of Natural Sedimentary and Synthetic Zeolites. Minerals Engineering, 8, 535-548. https://doi.org/10.1016/0892-6875(95)00015-I

[39] Margeta, K., Farkas, A., Šiljeg, M. and Logar, N.Z. (2013) Natural Zeolites in Water Treatment-How Effective is Their Use. INTECH Open Access Publisher, ISBN 978-953-51-0928-0.

[40] Hedström, A. (2001) Ion Exchange of Ammonium in Zeolites: A Literature Review. Journal of Environmental Engineering, 127, 673-681. https://doi.org/10.1061/(ASCE)0733-9372(2001)127:8(673)

[41] Moulder, J.F., Chastain, J. and King, R.C., Eds. (1995) Handbook of X-Ray Photoelectron Spectroscopy: A Reference Book of Standard Spectra for Identification and Interpretation of XPS Data. Eden Prairie, Minn, Physical Electronics Division, Perkin-Elmer Corp.

[42] Huang, M., Adnot, A. and Kaliaguine, S. (1992) Characterization of Basicity in Alkaline Cation Faujasite Zeolites-An XPS Study Using Pyrrole as a Probe Molecule. Journal of Catalysis, 137, 322-332. https://doi.org/10.1016/0021-9517(92)90160-J

[43] Gruenert, W., Muhler, M., Schroeder, K.P., Sauer, J. and Schloegl, R. (1994) Investigations of Zeolites by Photoelectron and Ion Scattering Spectroscopy. 2. A New Interpretation of XPS Binding Energy Shifts in Zeolites. The Journal of Physical Chemistry, 98, 10920-10929. https://doi.org/10.1021/j100093a039

[44] Thompson, R.W. and Huber, M.J. (1982) Analysis of the Growth of Molecular Sieve Zeolite $\mathrm{NaA}$ in a Batch Precipitation System. Journal of Crystal Growth, 56, 711722. https://doi.org/10.1016/0022-0248(82)90056-2

[45] Larsen, S.C. (2007) Nanocrystalline Zeolites and Zeolite Structures: Synthesis, Characterization, and Applications. The Journal of Physical Chemistry C, 111, 1846418474. https://doi.org/10.1021/jp074980m 
Submit or recommend next manuscript to SCIRP and we will provide best service for you:

Accepting pre-submission inquiries through Email, Facebook, LinkedIn, Twitter, etc. A wide selection of journals (inclusive of 9 subjects, more than 200 journals)

Providing 24-hour high-quality service

User-friendly online submission system

Fair and swift peer-review system

Efficient typesetting and proofreading procedure

Display of the result of downloads and visits, as well as the number of cited articles Maximum dissemination of your research work

Submit your manuscript at: http://papersubmission.scirp.org/

Or contact jmmce@scirp.org 